\title{
Theoretical Explanation of Reactivity and Stability of Phosphorus(V) Porphyrins
}

\author{
Ivan N. Meshkov, ${ }^{a @}$ Alexander G. Martynov, ${ }^{a}$ Aslan Yu. Tsivadze, ${ }^{\mathrm{a}, \mathrm{b}}$ \\ and Yulia G. Gorbunova ${ }^{\mathrm{a}, \mathrm{b}}$ \\ ${ }^{a}$ A.N. Frumkin Institute of Physical Chemistry and Electrochemistry of Russian Academy of Sciences, 119071 Moscow, \\ Russia \\ ${ }^{\mathrm{b}}$ N.S. Kurnakov Institute of General and Inorganic Chemistry of Russian Academy of Sciences, 119991 Moscow, Russia \\ ${ }^{\circledR}$ Corresponding authorE-mail: ivan.n.meshkov@gmail.com
}

\begin{abstract}
The reactivity of substituted meso-arylporphyrins towards complexation with phosphorus $(V)$ and stability of the series of $P(V)$ porphyrins was theoretically studied using DFT B3LYP/6-31G** calculations. The influence of both molecular geometry and electronic structure of porphyrins was estimated using calculated data: introduction of electronwithdrawing substituents into porphyrins results in lowering of complexation efficiency and in decrease of general stability of $P(V)$ porphyrin complexes. The obtained results correlate with the previously obtained experimental data and can be used for prediction of reactivity and stability of the novel $P(V)$ porphyrins.
\end{abstract}

Keywords: Phosphorus(V) porphyrins, DFT, electrostatic potential map.

\section{Теоретическое объяснение особенностей реакционной способности и устойчивости порфиринатов фосфора(V)}

\author{
И. Н. Мешков, ${ }^{a} @$ А. Г. Мартынов, ${ }^{a}$ А. Ю. Цивадзе, ${ }^{a, b}$ Ю. Г. Горбунова ${ }^{a, b}$ \\ ${ }^{a}$ Институт физической химии и электрохимии им. А.Н. Фрумкина Российской академии наук, 119071 Москва, Россия \\ ${ }^{\mathrm{b}}$ Институт общей и неорганической химии им. Н.С. Курнакова Российской академии наук, 119991 Москва, Россия \\ ${ }^{\circledR}$ E-mail: ivan.n.meshkov@gmail.com
}

\begin{abstract}
C применением метода DFT B3LYP/6-31G** была проведена теоретическая оценка реакционной способности мезо-арилпорфиринов в реакциях комплексообразования с фосфором $(V)$ и стабильности образуюшихся комплексов. Показано, что введение электроноакцепторных заместителей в молекуль порфиринов приводит к снижению эффективности реакиий комплексообразования и уменьшению стабильности порфиринатов фосфора $(V)$. Полученные результаты коррелируют с ранее полученнылми экспериментальными данными и могут быть использованы для предсказания реакционной способности и устойчивости новых порфиринатов $\operatorname{poc} \operatorname{popa}(V)$.
\end{abstract}

Ключевые слова: Порфиринаты фосфора(V), теория функционала плотности, карта электростатических потенциалов.

\section{Introduction}

Porphyrins and their derivatives are very attractive molecules for various applications: building blocks in supramolecular assemblies and coordination polymers, photocatalysts and singlet oxygen photosensitizers, mate- rials for photovoltaics and fuel cells, molecular machines etc. ${ }^{[1-7]}$ The coordination chemistry of porphyrins is extremely rich, i.e. there are many metal cations, which can be inserted into a porphyrin cavity. The smallest atom, which can be inserted into porphyrin in singular, is phosphorus. ${ }^{[8]}$ The chemistry of porphyrin complexes of phosphorus( $\mathrm{V})$ is well 
documented, whereas their phosphorus(III) analogues are unstable and cannot be isolated..$^{[9,10]}$

The size and the nature of the $\mathrm{P}(\mathrm{V})$ atom determine several unique features of the corresponding porphyrin complexes, such as a character of $\mathrm{P}-\mathrm{N}$ bonds, that is much more covalent in comparison with coordination and ionic bonds formed by metal ions with nitrogen atoms of porphyrin macrocycles. ${ }^{[8]}$ Moreover, $\mathrm{P}-\mathrm{N}$ bond is quite strong (for example, its energy in phosphorus nitride is $617 \mathrm{~kJ} / \mathrm{mol})^{[11]}$ and short $(1.6 \AA) \cdot{ }^{[12]}$ The mentioned facts lead to a strong deformation of the porphyrin ring ${ }^{[13-15]}$ and, consequently lowering of the stability of $\mathrm{P}(\mathrm{V})$ porphyrins. However, complexes with different meso- and $\beta$-substituents, as well as different axial ligands, demonstrate diverse stability: some of them can be stored at room temperature in the presence of light, other ones slowly decompose even in a fridge under argon in darkness. ${ }^{[15]}$ The same phenomena are observed for the synthetic procedures: reaction yields of the complex formation reaction vary from $13 \%$ to almost $90 \%$. $^{[15]}$

The first synthesis of $\mathrm{P}(\mathrm{V})$ meso-tetraphenylporphyrin derivative was described in 1977 by Carrano and Tsutsui. ${ }^{[16]}$ Approximately at the same time, the synthetic procedure towards $\mathrm{P}(\mathrm{V}) \beta$-octaethylporphyrin was published. ${ }^{\text {[9] }}$ Both methods are based on application of the chloride derivatives as the phosphorus source $\left(\mathrm{POCl}_{3}\right.$ and $\left.\mathrm{PCl}_{3}\right)$. However, these techniques are efficient only for the synthesis of porphyrins containing electron donating substituents either in meso- or $\beta$-positions. ${ }^{[17-20]}$ In the case of presence an electron withdrawing pyridyl substituent, this method loses its efficiency. Recently we have demonstrated the novel approach towards $\mathrm{P}(\mathrm{V})$ pyridyl-containing porphyrins, based on using more powerful metalating agent as $\mathrm{POBr}_{3} \cdot{ }^{[15,21]}$

Herein we present the theoretical explanation of the observed phenomena using DFT calculations. The investigation includes both optimization of the compound geometry and building up a map of the charge distribution within the porphyrin $\mathrm{P}(\mathrm{V})$ molecule. The obtained data allows to make the correlations between electronic structure of the macrocycle and its ability for phosphorus atom insertion into its cavity as well as the stability of the isolated $\mathrm{P}(\mathrm{V})$ porphyrins.

\section{Experimental}

The calculations were performed with Spartan'14 software (build 1.1.4, Wavefunction Inc.) under Windows 10 operating system. The structures were optimized towards the equilibrium geometry at the energy minimum. The gradient tolerance is $4.5 \cdot 10^{-4}$ hatree bohr $^{-1}$ and the distance tolerance is $1.8 \cdot 10^{-3} \AA$. The DFT calculations were performed with B3LYP/6-31G** level of theory. The electrostatic potential maps were plotted in high resolution.

The set of five free-base porphyrins (meso-tetraphenylporphyrin, meso-mono-, di- and tetra- $p$-pyridyl- as well as $m e s o$-mono- $p$-carboxyphenyl- and mono-p-pyridyldiphenylporphyrin (Figure 1)) was used for evaluation of their ability to coordinate a phosphorus atom into the macrocycle cavity. Two types of the described $\mathrm{P}(\mathrm{V})$ porphyrin derivatives with hydroxyl and ethoxyl axial ligands were studied (Figure 1) to estimate their stability.

\section{Results and Discussion}

Previously we have reported on the synthesis and investigation of the series of the phosphorus(V) meso-porphyrins with the different ratio of the phenyl and $p$-pyridyl substituents $\mathbf{1 b}-\mathbf{4 b}$. $^{[15,21]}$

As mentioned above, the dramatic difference in their behavior was found. We observed the following tendency: increasing of number of the meso-p-pyridyl units decreased efficiency of the phosphorus(V) insertion into the cavity and the general stability of the obtained complexes. In the case of the compound $\mathbf{1 b}$, the yield of complex formation reaction was $86 \%$ and the molecule was stable in solid state under air and daylight. By contrast, the complex $\mathbf{4 b}$ was obtained only in yield $13 \%$; it should be stored under argon in the absence of light and preferably in a fridge. Nevertheless, it slowly decomposes both to the corresponding free-base porphyrin and unrecognized brownish substance, that suggests decomposition of the macrocycle. The porphyrin 5a was not described previously, hence, its $\mathrm{P}(\mathrm{V})$ complexes $\mathbf{5 b}$ and $\mathbf{5 c}$ are also unknown. The evaluation of their properties can help in its further synthesis and characterization.

The described peculiarities of compound stabilities may be related to the geometry of $\mathrm{P}(\mathrm{V})$ meso-porphyrins.
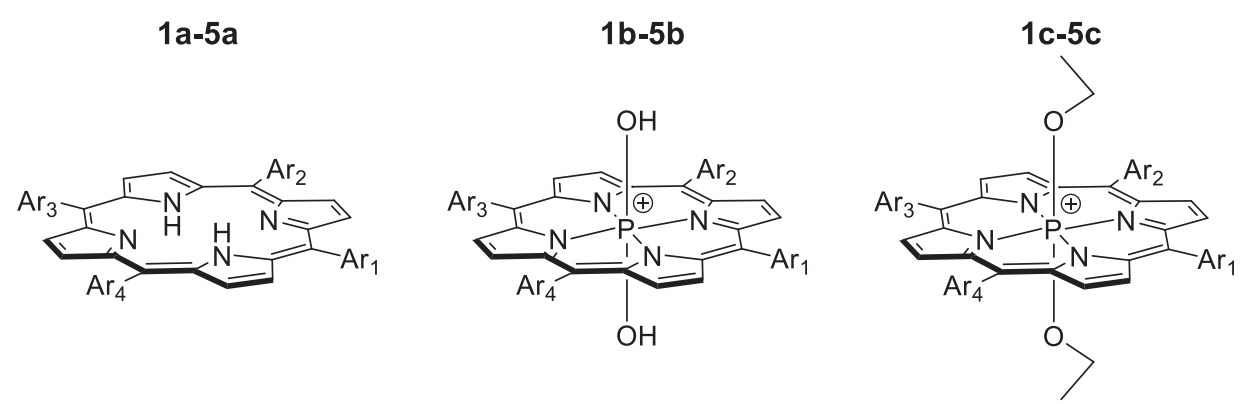

1a-1c: $A r_{1}=A r_{2}=A r_{3}=A r_{4}=$ phenyl

2a-2c: $A r_{1}=$ pyridyl; $\mathrm{Ar}_{2}=\mathrm{Ar}_{3}=\mathrm{Ar}_{4}=$ phenyl

3a-3c: $\mathrm{Ar}_{1}=\mathrm{Ar}_{3}=$ pyridyl; $\mathrm{Ar}_{2}=\mathrm{Ar}_{4}=$ phenyl

4a-4c: $A r_{1}=A r_{2}=A r_{3}=A r_{4}=$ pyridyl

5a-5c: $A r_{1}=$ pyridyl; $\mathrm{Ar}_{3}=$ carboxyphenyl; $\operatorname{Ar}_{2}=\mathrm{Ar}_{4}=$ phenyl

Figure 1. Structures of the studied free-base porphyrins and their phosphorus(V) complexes. 
Table 1. Comparison of the calculated and experimental geometry parameters for porphyrins $\mathbf{1} \mathbf{b}$ and $\mathbf{2} \mathbf{b} .^{[13,15]}$

\begin{tabular}{ccccc}
\hline Parameter & 1b Crystal data & 1b Calculation & 2b Crystal data & 2b Calculation \\
\hline P-O bonds, $\AA$ & $1.546(8), 1.644(8)$ & 1.673 & $1.605(3), 1.627(3)$ & 1.676 \\
P-N bonds, $\AA$ & $1.870(10)-1.916(11)$ & $1.870-1.894$ & $1.846(4)-1.870(4)$ & $1.846-1.889$ \\
Angle between N4 and C4 planes & $20.75^{\circ}-32.10^{\circ}$ & $24.83^{\circ}-26.64^{\circ}$ & $25.46^{\circ}-32.40^{\circ}$ & $25.78^{\circ}-28.26^{\circ}$ \\
\hline
\end{tabular}

The crystal structures of the described complexes clearly demonstrate dramatic "ruffled" deformation of the macrocycle ring. ${ }^{[13]}$ Thus, correct modelling of the complex geometry is one of the key points of the current studying. For the geometry optimization we used DFT method (see Experimental section). The obtained results correlate well with the experimental structural data. Backbones of freebase porphyrins have planar geometry, whereas their $\mathrm{P}(\mathrm{V})$ complexes are significantly distorted. Several crystal structures of the $\mathrm{P}(\mathrm{V})$ meso-tetraphenylporphyrin complexes were described previously. ${ }^{[13,15]}$ The geometry of $\mathbf{1 b}$ and $\mathbf{2 b}$ from the experimental data is in good accordance with the corresponding calculated molecules (Figure S1).

One of the main parameters for the evaluation of the macrocycle deformation is an angle between N4 plane of the porphyrin core and $\mathrm{C} 4$ planes of the macrocycle periphery. Each $\mathrm{C} 4$ plane includes one meso-carbon and three adjacent carbon atoms. Generally, the angle is $0^{\circ}$ (i.e. the porphyrin periphery and its inner nitrogen atoms are located within one plane. ${ }^{[22]}$ However, in the case of phosphorus(V) complexes this angle reaches $32^{\circ}$ for $\mathbf{1 b}$ and $\mathbf{2 b}$ porphyrins (Table 1). The calculated values of the angles are in good agreement with the $\mathrm{X}$-ray data. Calculated and experimental values of the key parameters such as $\mathrm{P}-\mathrm{N}$ and $\mathrm{P}-\mathrm{O}$ bonds lengths are also similar.

In order to estimate an ability towards the complexation reaction with the phosphorus atom, the electrostatic potential maps of the studied free-base porphyrins were calculated (Figure 2). The value of the potential refers to an interaction energy of a point positive charge and the studied molecule. ${ }^{[23]}$ Thus, in the case of a positive charge located somewhere, this area repulses the positive charge, i.e. the electrostatic potential is positive; in the opposite case, it is negative.

From the Figure 2 it is clear, that the presence of the electron withdrawing substituents, such as pyridyls or carboxyphenyls, leads to decrease of the electronic density on the inner nitrogen atoms of the porphyrin ring. During the metalation reaction, the macrocycle cavity accepts very small (calculated ionic radius is $38 \mathrm{pm})^{[24]}$ and highly positive charged $(+5)$ phosphorus atom. The usual length of $\mathrm{P}-\mathrm{N}$ bond is $c a$. $1.6 \AA^{[12]}$ and the approximate diameter of the cavity is $c a .4 \AA^{[22]}$ Thus, the complexation process induces the deformation of the planar porphyrin ring. Evidently, decreasing $\delta$ - charge on the central nitrogen atoms may hinder the metalation reaction. The calculated electrostatic potentials for the mentioned atoms are $-155 \mathrm{~kJ} / \mathrm{mol}$ (1a), $-131 \mathrm{~kJ} / \mathrm{mol}$ (2a), $-127 \mathrm{~kJ} / \mathrm{mol}$ (3a), $-101 \mathrm{~kJ} / \mathrm{mol}$ (4a) and $-115 \mathrm{~kJ} / \mathrm{mol}$ (5a). Insertion of, at least, one pyridyl unit dramatically decreases an ability towards $\mathrm{P}(\mathrm{V})$ coordination reaction, however, the influence of the second unit is not so significant. Addition of the third and fourth pyridyl mesosubstituents causes the effect of the same value, as the first one. The calculated data well correlates with the previously described experimental data ${ }^{[15]}$ Metalation of 2a in comparison with 1a requires more $\mathrm{POBr}_{3}$ (40 eq. instead of 25 eq.) and more time ( $90 \mathrm{~min}$ instead of $80 \mathrm{~min}$ ); and the reaction yields are $86 \%$ of final product instead of $95 \%$. The reaction of the compound 3a with 53 eq. of $\mathrm{POBr}_{3}$ in 90 min yields 3b in $69 \%$, whereas in the case of $\mathbf{4 a}$ : 100 eq. of $\mathrm{POBr}_{3}$ during 150 min leads to $\mathbf{4 b}$ in $13 \%$. In the case of unknown 5a we can estimate efficiency of the phosphorus(V) complex formation reaction somewhere between $\mathbf{3 a}$ and $\mathbf{4 a}$. The predicted reaction yield can be expected as the value of $\sim 40-50 \%$.

The electrostatic potential maps of $\mathrm{P}(\mathrm{V})$ porphyrin complexes $\mathbf{1 b - 5 b}$ containing hydroxyl ligands in the axial positions are also of interest (Figure 3). Comparison of the calculated potentials of the free-base porphyrins (1a for example, Figure S2) and the corresponding phosphorus(V) complex 1b demonstrate dramatic change of its values within the whole molecule. Positive charge is not located exactly in the center of the complex, but it is delocalized even onto the meso-phenyl units. The electro-

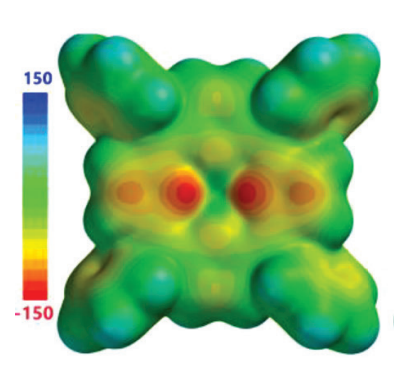

1a

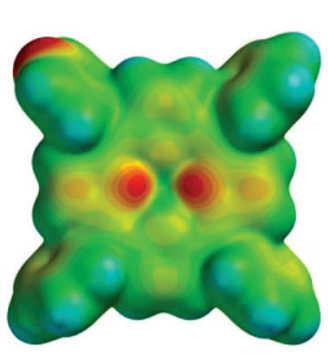

$2 a$

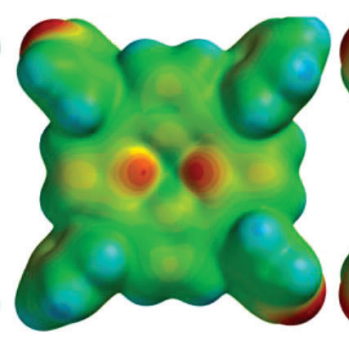

3a

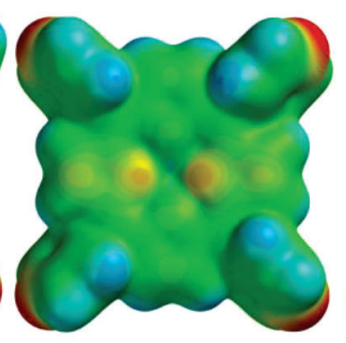

$4 a$

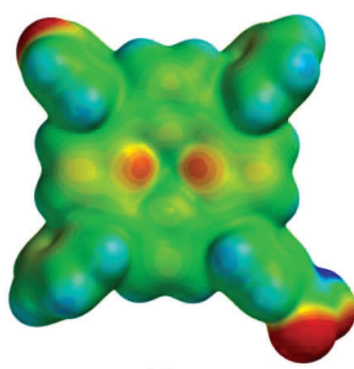

$5 a$

Figure 2. The calculated electrostatic potential maps of the free-base porphyrins $\mathbf{1 a - 5 a}$; the range of the potential is $-150-150 \mathrm{~kJ} / \mathrm{mol}$. 


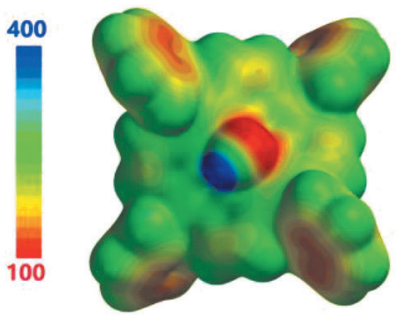

$1 \mathbf{b}$

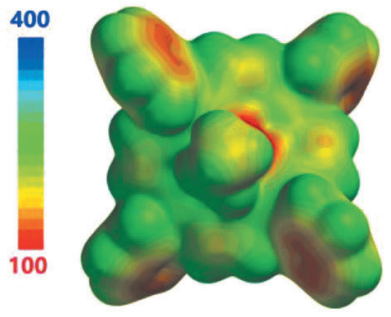

$1 c$

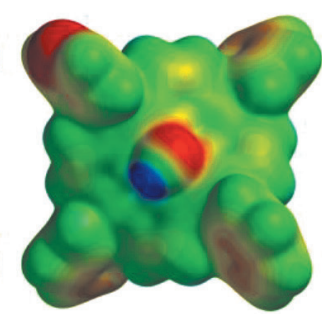

$2 \mathbf{b}$

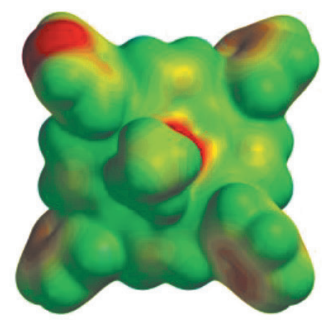

2c

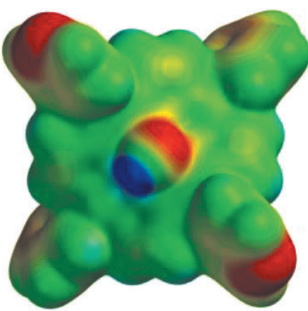

$3 \mathbf{b}$

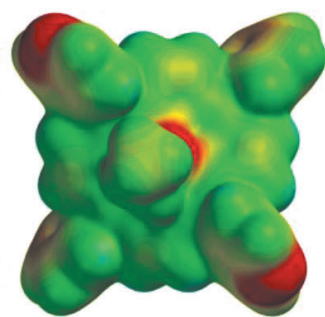

3c

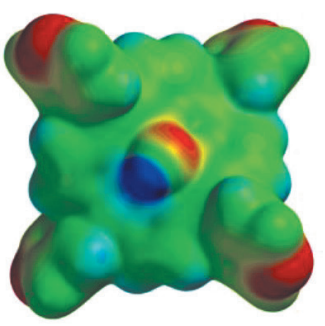

$4 b$

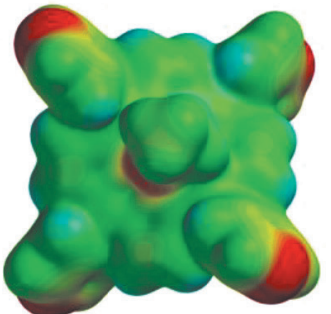

4c

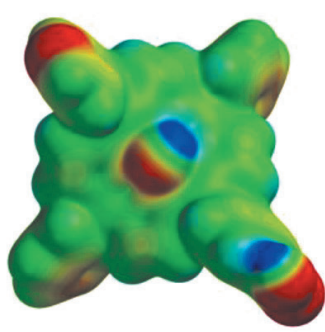

$5 \mathbf{b}$

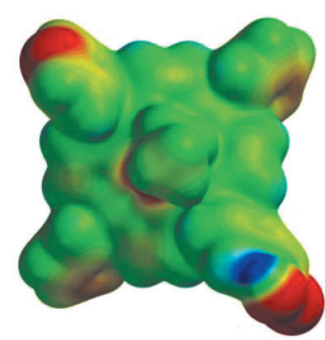

$5 c$

Figure 3. The calculated electrostatic potential maps of the phosphorus $(\mathrm{V})$ porphyrins $\mathbf{1 b}-\mathbf{5 b}$ and $\mathbf{1} \mathbf{c}-\mathbf{5} \mathbf{c}$; the range of the potential is $100-400 \mathrm{~kJ} / \mathrm{mol}$.

static potentials of the meso-phenyl hydrogen atoms change from $c$ a $50-70 \mathrm{~kJ} / \mathrm{mol}$ to $c a$. $240-290 \mathrm{~kJ} / \mathrm{mol}$. The same effect is observed for other studied compounds (Figure S2). Simultaneously, hydrogen atoms of OH-groups have potential over $450 \mathrm{~kJ} / \mathrm{mol}$. The difference with the oxygen atom is $389-391 \mathrm{~kJ} / \mathrm{mol}$, that means the "acidic" nature of the corresponding hydrogens. This fact combined with a strength of $\mathrm{P}-\mathrm{O}$ bond $(597 \mathrm{~kJ} / \mathrm{mol}){ }^{[11]}$ explains inability to substitute hydroxyl axial ligands with an alkylation/arylation agent; pretreatment with a reactive axial ligand (like $\mathrm{Cl}^{-}$or $\mathrm{Br}^{-}$) is required..$^{[21]}$ This pathway allows further modification of the $\mathrm{P}(\mathrm{V})$ porphyrin molecule.

Calculated electrostatic potential maps of diethoxyaxially substituted phosphorus(V) porphyrins are similar to their hydroxyl derivatives (Figure 3). The potential, in general, is $5-10 \mathrm{~kJ} / \mathrm{mol}$ lower, meaning small compensation effect of the electron donating ethoxyl ligands onto the positively charged complex. It can lead to slight stabilization of the complex, but this effect requires further experimental investigation.

It is worth to note, that the additional reason of the low general stability of the described hydroxysubstituted phosphorus(V) porphyrins within the row $\mathbf{1 b}>$ $\mathbf{2 b}>\mathbf{3 b}>\mathbf{4 b}$ may be due to growth in their basicity due to increasing number of pyridyl units. Interactions between them and acidic hydrogens of $\mathrm{OH}$ axial ligands may involve deprotonation and further destabilization of the whole phosphorus(V) complex. The ethoxy-protected $\mathrm{P}(\mathrm{V})$ complexes may avoid this issue. However, this assumption needs further investigation.

\section{Conclusions}

In summary, our results give brief theoretical explanation on the behavior features of such unusual metalloporphy- rins, as phosphorus(V) complexes. The powerful DFT technique (B3LYP/6-31G**) provides the informative data about geometry and charge distribution of the studied compounds.

The analysis of the series of similar complexes with different electron-withdrawing meso-substituents allows to determine reasons of significant difference in the efficiency of their synthesis and their general stability. The obtained data can be used for prediction of properties of the unknown $\mathrm{P}(\mathrm{V})$ complexes and suggest recommendations towards their synthesis. The described data can be used for an assessment the further synthetic projects within the field of phosphorus( $\mathrm{V})$ porphyrins.

Acknowledgements. Authors are grateful to the Russian Science Foundation (\#17-73-10469) for the financial support.

\section{References}

1. Satake A., Kobuke Y. Tetrahedron 2005, 61, 13-41.

2. Beletskaya I.P., Tyurin V.S., Tsivadze A.Y., Guilard R., Stern C. Chem. Rev. 2009, 109, 1659-1713.

3. Durot S., Taesch J., Heitz V. Chem. Rev. 2014, 114, 8542-8578.

4. Park J., Feng D., Yuan S., Zhou H.-C.C. Angew. Chem. Int. Ed. 2015, 54, 430-435.

5. Lang K., Mosinger J., Wagnerová D.M. Coord. Chem. Rev. 2004, 248, 321-350.

6. Erbas-Cakmak S., Leigh D.A., McTernan C.T., Nussbaumer A.L. Chem. Rev. 2015, 115, 10081-10206.

7. Day N.U., Wamser C.C., Walter M.G. Polym. Int. 2015, 64, 833-857.

8. Sanders J.K.M., Bampos N., Clyde-Watson Z., Darling S.L., Hawley J.C., Kim H.-J., Mak C.C., Webb S.J. In: The Porphyrin Handbook. Volume 3. Inorganic, Organometallic and Coordination Chemistry, 2000. pp. 3-40.

9. Sayer P., Gouterman M., Connell C.R. J. Am. Chem. Soc. 1977, 99, 1082-1087. 
10. Gouterman M., Sayer P., Shankland E., Smith J.P. Inorg. Chem. 1981, 20, 87-92.

11. Luo Y.-R. Comprehensive Handbook of Chemical Bond Energies, Boca Raton: CRC Press, 2007.

12. Bartlett S.W., Coles S.J., Davies D.B., Hursthouse M.B., Ibişoğlu H., Kiliç A., Shaw R.A., Ün I. Acta Crystallogr., Sect. B: Struct. Sci. 2006, 62, 321-329.

13. Mangani S., Meyer E.F., Cullen D.L., Tsutsui M., Carrano C.J. Inorg. Chem. 1983, 22, 400-404.

14. Lin Y.-H., Sheu M.-T., Lin C.-C., Chen J.-H., Wang S.-S. Polyhedron 1994, 13, 3091-3097.

15. Meshkov I.N., Bulach V., Gorbunova Y.G., Kyritsakas N., Grigoriev M.S., Tsivadze A.Y., Hosseini M.W. Inorg. Chem. 2016, 55, 10774-10782.

16. Carrano C.J., Tsutsui M. J. Coord. Chem. 1977, 7, 79-83.

17. Hirakawa K., Ouyang D., Ibuki Y., Hirohara S., Okazaki S., Kono E., Kanayama N., Nakazaki J., Segawa H. Chem. Res. Toxicol. 2018, 31, 371-379.
18. Ryan A.A., Ebrahim M.M., Petitdemange R., Vaz G.M., Paszko E., Sergeeva N.N., Senge M.O. Photodiagnosis Photodyn. Ther. 2014, 11, 510-515.

19. Poddutoori P.K., Lim G.N., Pilkington M., D'Souza F., van der Est A. Inorg. Chem. 2016, 55, 11383-11395.

20. Akiba K.Y., Nadano R., Satoh W., Yamamoto Y., Nagase S., Ou Z., Tan X., Kadish K.M. Inorg. Chem. 2001, 40, 5553-5567.

21. Meshkov I.N., Bulach V.V., Gorbunova Y.G., Gostev F.E., Nadtochenko V.A., Tsivadze A.Y., Hosseini M.W. Chem. Commun. 2017, 53, 9918-9921.

22. Byrn M.P., Curtis C.J., Goldberg I., Hsiou Y., Khan S.I., Sawin P.A., Tendick S.K., Strouse C.E. J. Am. Chem. Soc. 1991, 113, 6549-6557.

23. Hehre W., Ohlinger S. Spartan'14. Tutorial and User's Guide, Wavefunction, Inc., 2014.

24. Shannon R.D. Acta Crystallogr. 1976, A32, 751-767.

Received 21.02.2019 Accepted 21.03.2019 